\title{
Mineral Resources of the Mancos Mesa Wilderness Study Area, San Juan County, Utah
}

\section{U.S. GEOLOGICAL SURVEY BULLETIN 1755-A}
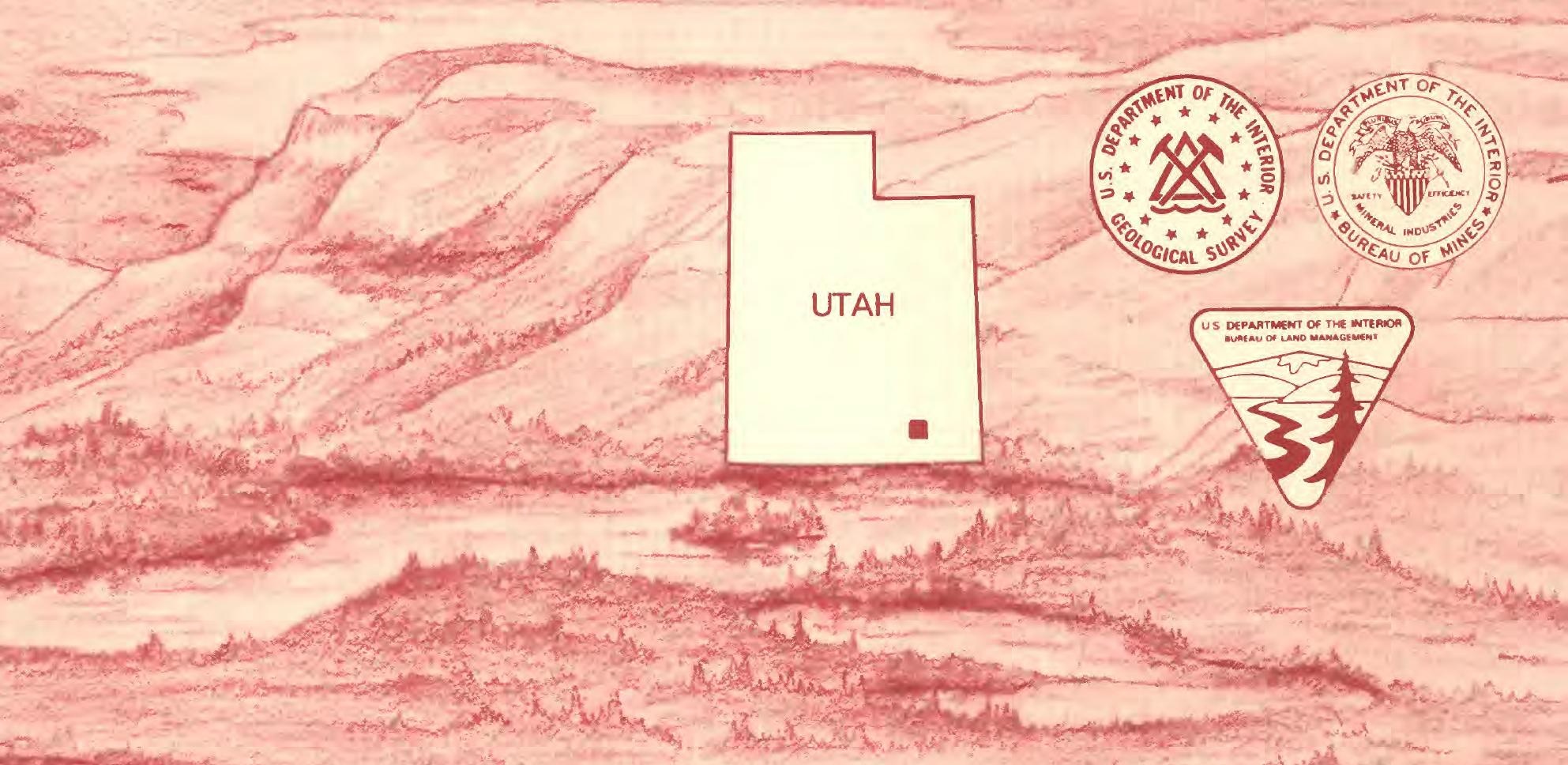

Chapter A

\section{Mineral Resources of the Mancos Mesa Wilderness Study Area, San Juan County, Utah}

By FORREST G. POOLE, GEORGE A. DESBOROUGH, HARLAN N. BARTON, WILLIAM F. HANNA, and KEENAN LEE U.S. Geological Survey

RICHARD F. KNESS

U.S. Bureau of Mines 
DEPARTMENT OF THE INTERIOR

MANUEL LUJAN, JR., Secretary

U.S. GEOLOGICAL SURVEY

Dallas L. Peck, Director

Any use of trade, product, or firm names in this publication is for descriptive

purposes only and does not imply endorsement by the U.S. Government.

UNITED STATES GOVERNMENT PRINTING OFFICE: 1989

For sale by the

Books and Open-File Reports Section

U.S. Geological Survey

Federal Center

Box 25425

Denver, CO 80225

\section{Library of Congress Cataloging-in-Publication Data}

Mineral resources of the Mancos Mesa Wilderness Study Area, San Juan County, Utah / by Forrest G. Poole ... [et al.].

p. $\quad$ cm. -- (Mineral resources of wilderness study areas--Red House Cliffs

region, Utah : ch. A) (U.S. Geological Survey bulletin ; 1755-A)

Includes bibliographical references.

Supt. of Docs. no.: I 19.3: 1755A

1. Mines and mineral resources-Utah-Mancos Mesa Wilderness.

2. Mancos Mesa Wilderness (Utah) I. Poole, F. G. (Forrest Graham),

1929- .II. Series. III. Series: U.S. Geological Survey bulletin ; 1755-A.

QE75.B9 no. 1755-A

[TN24.U8]

$557.3 \mathrm{~s}-\mathrm{dc} 20$

[553'.09792'59]

89-600205 


\section{STUDIES RELATED TO WILDERNESS}

\section{Bureau of Land Management Wilderness Study Areas}

The Federal Land Policy and Management Act (Public Law 94-579, October 21, 1976) requires the U.S. Geological Survey and the U.S. Bureau of Mines to conduct mineral surveys on certain areas to determine the mineral values, if any, that may be present. Results must be made available to the public and be submitted to the President and the Congress. This report presents the results of a mineral survey of the Mancos Mesa Wilderness Study Area (UT-060-181), San Juan County, Utah. 



\title{
CONTENTS
}

\author{
Abstract A1 \\ Summary A1 \\ Character and setting A1 \\ Identified mineral resources $\mathbf{A 1}$ \\ Mineral resource potential A1 \\ Introduction $\mathbf{A 2}$ \\ Investigations by the U.S. Bureau of Mines $\quad \mathbf{A 2}$ \\ Investigations by the U.S. Geological Survey $\quad$ A4 \\ Appraisal of identified resources A4 \\ Mining activity A4 \\ Oil and gas A5 \\ Sand, gravel, and stone A5 \\ Assessment of potential for undiscovered resources $\quad$ A7 \\ Geology $\quad$ A7 \\ Geochemistry A7 \\ Geophysics A8 \\ Aeromagnetic and gravity data \\ A8 \\ Remote-sensing data A8 \\ Aerial radiometric data $\mathbf{A 1 0}$ \\ Mineral and energy resources $\quad$ A10 \\ Uranium A10 \\ Metals other than uranium $\quad$ A11 \\ Oil and gas A11 \\ Coal A12 \\ Geothermal energy A12 \\ References cited $\quad \mathbf{A 1 2}$ \\ Appendix A15 \\ 7 \\ PLATE
}

[Plate is in pocket]

1. Map showing mineral resource potential and geology of the Mancos Mesa Wilderness Study Area

\section{FIGURES}

1-3. Maps of the Mancos Mesa Wilderness Study Area showing:

1. Mineral resource potential, location, and lineaments A3

2. Oil and gas leases and wells, and mineralized paleochannels

3. Aeromagnetic anomalies A9 


\title{
Mineral Resources of the Mancos Mesa Wilderness Study Area, San Juan County, Utah
}

\author{
By Forrest G. Poole, George A. Desborough, Harlan N. Barton, \\ William F. Hanna, and Keenan Lee \\ U.S. Geological Survey
}

Richard F. Kness

U.S. Bureau of Mines

\begin{abstract}
The U.S. Geological Survey and the U.S. Bureau of Mines conducted investigations to appraise the identified mineral resources (known) and assess the mineral resource potential (undiscovered) of 51,440 acres of the Mancos Mesa (UT-060-181) Wilderness Study Area, San Juan County, Utah. The wilderness study area has no identified resources. It has moderate mineral resource potential for uranium and moderate energy resource potential for oil and gas. Moderate mineral resource potential for uranium in channelfill sandstones exists in the Shinarump Member of the Chinle Formation in the subsurface beneath Mancos Mesa. The wilderness study area has low mineral resource potential for other metals, coal, and geothermal energy.
\end{abstract}

\section{SUMMARY}

\section{Character and Setting}

The Mancos Mesa Wilderness Study Area is in southeastern Utah about $50 \mathrm{mi}$ (miles) west of Blanding, Utah, which is the nearest population center (fig. 1). Dirt roads from paved Utah State Highway 263 on the south provide access to the eastern and southern margins of the study area. Boat landings and foot trails from Lake Powell on the west and north provide access to the western and northern margins of the study area. The interior of the study area is inaccessible except by arduous climbing and hiking or by helicopter because of vertical cliffs developed in thick sandstone units of the Lower Jurassic (see geologic time chart in appendix) Glen Canyon Group (Wingate Sandstone, Kayenta Formation, and Navajo Sandstone) (pl. 1).

Manuscript approved for publication, June 14, 1989.
Elevations within the study area range between 3,970 and $6,447 \mathrm{ft}$ (feet).

Mancos Mesa is a gently west dipping $\left(1-4^{\circ}\right)$ section of Permian to Jurassic sedimentary rocks (pl. 1). The main structures in the map area consist of joints and high-angle faults of relatively small displacement that trend northeast, north, and northwest. Joints are nearly vertical and are most conspicuous in the well-cemented sandstone of the Glen Canyon Group. The mapped high-angle faults have measurable stratigraphic offsets from a few feet to as much as $235 \mathrm{ft}$.

\section{Identified Mineral Resources}

No mineralized areas or prospects are present at the surface inside the study area. The Mancos Mesa Wilderness Study Area therefore has no identified resources. Prospecting for uranium has taken place in the southeastern part of the study area, and underground mining has taken place beneath the southeasternmost corner at the Markey mine. The amount of uranium remaining in the workings is unknown.

\section{Mineral Resource Potential}

Analyses of outcrop samples indicate slightly anomalous concentrations of arsenic, barium, beryllium, boron, cadmium, calcium, cobalt, copper, gallium, iron, lanthanum, lead, magnesium, manganese, molybdenum, nickel, phosphorus, scandium, selenium, silver, sodium, strontium, titanium, uranium, vanadium, yttrium, zinc, and zirconium in as many as 23 percent of the samples. Of the 24 stream-sediment samples collected inside the wilderness study area, 2 to 24 contain slightly anomalous concentrations of barium, boron, chromium, iron, magnesium, manganese, and zirconium, compared to average sandstone (Turekian 
and Wedepohl, 1961). Three or more of five stream-sediment samples from Red Canyon, less than 1 mi east of the eastern boundary of the wilderness study area, have slightly anomalous concentrations of barium, boron, cadmium, cobalt, copper, iron, lead, magnesium, manganese, nickel, niobium, scandium, strontium, titanium, vanadium, zinc, and zirconium, compared to average sandstone (Turekian and Wedepohl, 1961). These anomalous samples represent detrital material derived mainly from the Chinle Formation that crops out in Red Canyon and also underlies Mancos Mesa.

Uranium occurs in sandstone beds of the Shinarump Member of the Upper Triassic Chinle Formation in the Red Canyon area just east of the wilderness study area boundary. Workings of the Markey mine in Red Canyon follow the uranium mineralized rock in a Shinarump paleochannel that trends southwest under the southeasternmost corner of the study area. The projection of Shinarump paleochannel trends toward the study area and the presence of lithofacies related to uranium mineralization indicate that the Shinarump under Mancos Mesa has a moderate mineral resource potential for uranium (fig. 1).

Geologic surveys of the study area and vicinity (Thaden and others, 1964; Mullens, 1960; Hackman and Wyant, 1973) and studies of southeastern Utah (Irwin and others, 1980; Molenaar and Sandberg, 1983) indicate that the study area has a moderate energy resource potential for oil and gas (fig. 1). Paleozoic rocks that contain oil and gas elsewhere in the region are known to occur in the subsurface of the study area. The study area has a low resource potential for metals other than uranium, coal, and geothermal energy (fig. 1). No coal or thermal springs were noted in the study area.

\section{INTRODUCTION}

This report presents an evaluation of the mineral endowment (identified resources and mineral resource potential) of the study area and is the product of several separate studies by the U.S. Bureau of Mines (USBM) and the U.S. Geological Survey (USGS). Identified resources are classified according to the system of the U.S. Bureau of Mines and the U.S. Geological Survey (1980), which is shown in the appendix of this report. Identified resources are studied by the USBM. Mineral resource potential is the likelihood of occurrence of undiscovered metals and nonmetals, industrial rocks and minerals, and of undiscovered energy sources (coal, oil, gas, oil shale, and geothermal sources). It is classified according to the system of Goudarzi (1984) and is shown in the appendix. Undiscovered resources are studied by the USGS.

The USBM studied mineral resources, and the USGS studied mineral and energy resource potential of the 51,440-acre Mancos Mesa Wilderness Study Area (UT-060-181) in San Juan County, Utah (fig. 1), at the request of the U.S. Bureau of Land Management (BLM). In this report, the area studied is referred to as the "wilderness study area" or the "study area." Field studies of the area were conducted during May 1987 by USGS geologists and geochemists, and by USBM geologists.

The study area is on the western flank of the Monument uplift about $50 \mathrm{mi}$ west of Blanding, Utah, and lies just east of Lake Powell. The Glen Canyon National Recreation Area borders the western and northern sides of the study area and includes Lake Powell. The eastern boundary coincides with the precipitous cliff along the west side of northwest-trending Red Canyon, and the southern boundary was drawn along the northern side of west-trending Moqui (Moki) Canyon. Both Red and Moqui Canyons drain into Lake Powell. The interior of the study area is inaccessible except by arduous climbing and hiking or by helicopter because of vertical cliffs developed in thick sandstone units of the Glen Canyon Group (pl. 1).

Dirt roads from paved Utah State Highway 263 on the south provide access to the eastern and southern margins of the study area (pl. 1). Boat landings and foot trails from Lake Powell on the west and north provide access to the western and northern parts of the study area (pl. 1). Mancos Mesa, like many mesas and buttes in the canyonlands of the Colorado Plateau physiographic province, is sparsely vegetated by desert shrubs. The mesa top has scattered blackbrush, buffaloberry, Mormon tea, cactus, cliffrose, and Indian ricegrass (Don Englishman, BLM, written commun., 1982). Widely scattered piñon and juniper trees occur in some places. Blackbrush and sagebrush are in canyon bottoms along with scattered piñon and juniper. Sparse cottonwood trees, tamerisk, and riparian vegetation are in the canyons around the few springs and seeps. Elevations within the study area range from about $3,970 \mathrm{ft}$ along the western boundary to $6,447 \mathrm{ft}$ along the eastern boundary (pl. 1).

Mancos Mesa was named after Mancos Jim, a Piute Indian who hid in this remote area after the battle at White Canyon in 1884 (Don Englishman, BLM, written commun., 1982).

\section{Investigations by the U.S. Bureau of Mines}

Personnel of the USBM searched literature and compiled information on mining, oil and gas leases, mineral leases, and mining claims. Field work by USBM personnel consisted of examination of prospects and mines near the study area. Detailed descriptions of analytical procedures and results were reported by Kness (1988). Copies are available from the U.S. Bureau of Mines, Intermountain Field Operations Center, Box 25086, Denver Federal Center, Denver, CO 80225. 

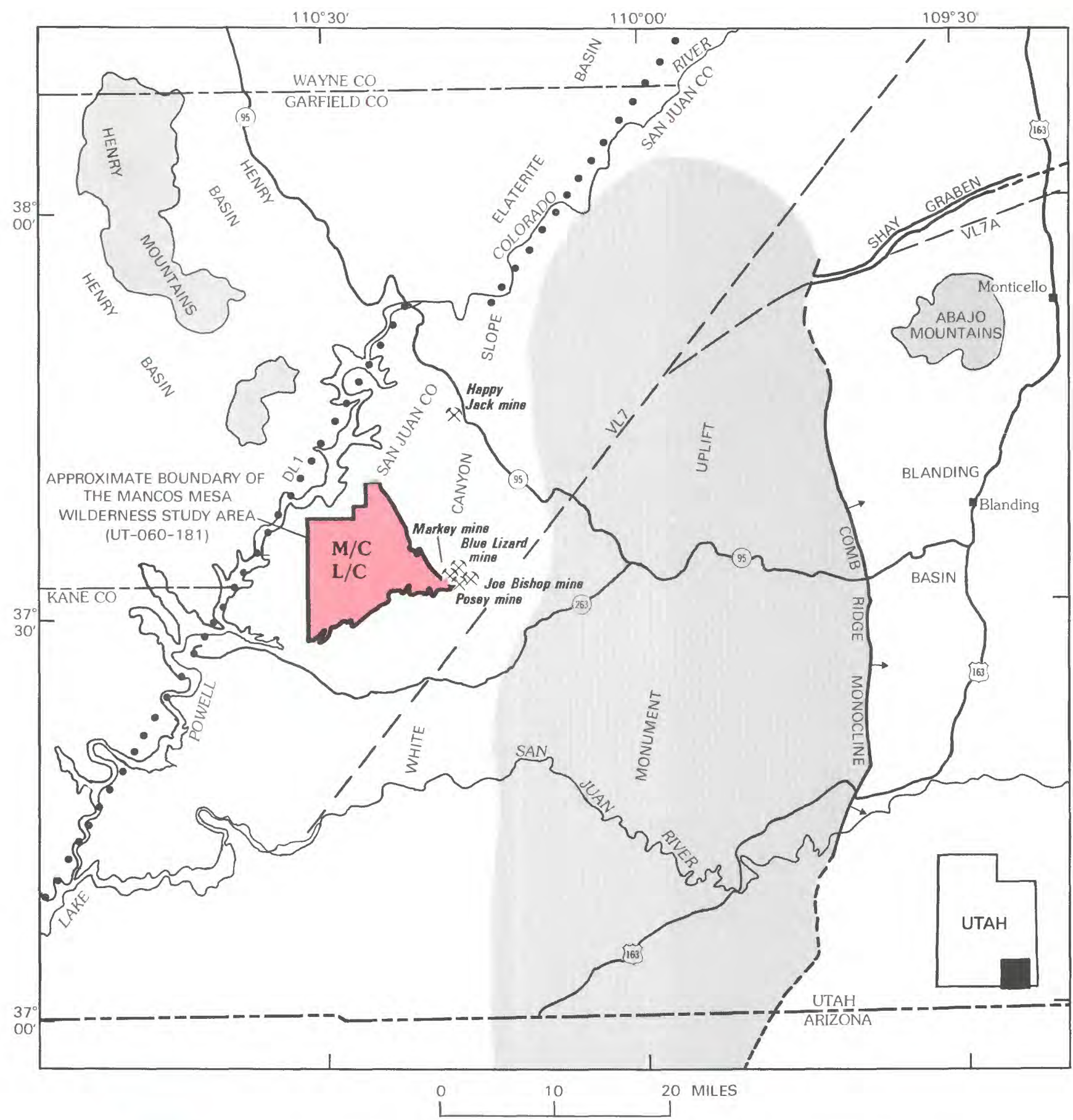

EXPLANATION

$\mathrm{M} / \mathrm{C}$
$\mathrm{L} / \mathrm{C}$ $\begin{array}{r}\begin{array}{c}\text { Geologic terrane having moderate mineral and energy resource potential for uranium and oil and gas, with cer- } \\ \text { tainty level } \mathrm{C} \text {; and low mineral and energy resource potential for other metals, coal, and geothermal energy. } \\ \text { all with certainty level } \mathrm{C}-\text { Applies to entire study area }\end{array} \\ \text { Level of certainty }\end{array}$

C Data indicate geologic environment and indicate level of resource potential

Figure 1. Mineral resource potential, location, and lineaments of the Mancos Mesa Wilderness Study Area, San Juan County, Utah. 


\section{Investigations by the}

\section{U.S. Geological Survey}

Personnel of the USGS collected 36 streamsediment and 36 heavy-mineral-concentrate dual samples from active alluvium at 36 sites in drainages in and around the study area. These samples represent the rocks within the drainage basin upstream from each sample locality. The stream-sediment and the nonmagnetic fraction of panned heavy-mineral concentrate were chemically analyzed. Detailed descriptions of analytical procedures and results are in Bullock and others (in press).

An existing 1:250,000-scale geologic map of the Escalante $1^{\circ} \times 2^{\circ}$ quadrangle (Hackman and Wyant, 1973), a 1:62,500-scale geologic map of the Clay Hills area (Mullens, 1960), and a 1:48,000-scale geologic map of the White Canyon area (Thaden and others, 1964) were examined, and a photogeologic study of the area was conducted prior to field work by USGS personnel. Geologic mapping techniques appropriate to preparation of a 1:24,000-scale geologic map were employed, utilizing aerial photographs. A Kern PG-2 high-order photogrammetric stereoscopic plotting instrument was used to compile the final 1:50,000-scale geologic map (pl. 1). Strike and dip of beds and thickness of formations were determined from points measured on outcropping beds on aerial photographs using the digitized photogrammetric instrument. Outcrops were examined for signs of mineralized rock. During mapping, 82 samples of selected rock units were collected from the Triassic and Jurassic formations for petrographic examination and for element analysis.

The mineral resource potential of the Mancos Mesa Wilderness Study Area described here is based on data from many sources. Among these are studies of the geology and mineral deposits of the Escalante $1^{\circ} \times 2^{\circ}$ quadrangle (Hackman and Wyant, 1973), the Clay Hills area (Mullens, 1960), and the White Canyon area (Thaden and others, 1964), a reconnaissance study of mineral resources in the study area (Science Applications, Inc., 1982), a study of identified mineral resources by the USBM (Kness, 1988), a geochemical data summary for stream-sediment samples (Barton, this report; Bullock and others, in press), a study of the geology of the Mancos Mesa area (Poole and Desborough, this report), an evaluation of petroleum potential (Poole and Kness, this report), an interpretation of aeromagnetic and gravity data (Hanna, this report), a remote sensing study based on Landsat Multispectral Scanner imagery and Landsat Thematic Mapper data (Lee, this report), and an interpretation of radiometric data (J.S. Duval, written commun., 1987).

Acknowledgments.-Calvin Black of Blanding, Utah, provided unpublished maps of the Markey mine in
Red Canyon and drill-hole data from Moqui Canyon. T.E. Dill of Amoco Production Co. provided a geologic summary and core data for the Mancos Mesa No. 1-B drill hole. We acknowledge the assistance of our helicopter pilot, Darrell Stubbs, whose skill as a pilot made the geologic mapping and sampling in remote areas considerably easier.

\section{APPRAISAL OF IDENTIFIED RESOURCES}

By Richard F. Kness

U.S. Bureau of Mines

\section{Mining Activity}

Prospecting for uranium has taken place in the eastern part of the study area, and underground mining has been done beneath the southeasternmost corner (Markey mine). No mineralized areas were identified, and no prospects were found at the surface inside the wilderness study area.

Unpatented mining claims are inside the study area (Kness, 1988, pl. 1). Gulf Mineral Resources Co. staked claims covering a large part of the study area and drilled numerous uranium exploration holes in the southeastern part of the study area between late 1976 and late 1979. Gulfs Red Canyon project claims (Denny claims) were not shown by Kness $(1988$, pl. 1) because the claims were dropped in February 1983. Uranium exploration took place in the mid-1970's in Moqui Canyon outside the southeastern boundary.

The Red Canyon uranium area is in the White Canyon mining district just east of the study area (Chenoweth, 1975). Copper was discovered in the White Canyon mining district in the 1880 's. Some copper ore was shipped from the Happy Jack (Blue Dike) mine (fig. 1) in 1916 (Thaden and others, 1964). Butler and others (1920) reported the occurrence of uranium sulfates at the Happy Jack mine; uranium production began in 1949. The Red Canyon area was prospected intensely from 1948 to 1951 (Malan, 1968), and production began at the Joe Bishop and Posey mines (fig. 1) in 1951 and at the Blue Lizard mine (fig. 1) in 1954 (Thaden and others, 1964). These mines have been worked intermittently since the 1950's and were closed in the early 1980's due to low uranium prices.

Uranium mines associated with paleochannels filled with the Shinarump Member of the Chinle Formation are east of the study area in Red Canyon (pl. 1). The Blue Lizard and Posey mines, which are within $1.5 \mathrm{mi}$ of the eastern boundary of the study area, were described in detail by Thaden and others (1964). The Markey mine, about $4,000 \mathrm{ft}$ southwest of the Blue 
Lizard mine, was operating in the same Shinarump-filled paleochannel. This N. 20-25 E-trending paleochannel, which occurs at the top of the underlying Moenkopi Formation, is about $400 \mathrm{ft}$ wide, 18-25 ft deep, and traceable for about $6,000 \mathrm{ft}$ (Thaden and others, 1964). According to Thaden and others (1964), sandstone of the Shinarump in the paleochannel has an estimated ore grade ranging from 0.2 to 0.5 percent uranium oxide $\left(\mathrm{U}_{3} \mathrm{O}_{8}\right)$.

The Markey mine portal is about $4,000 \mathrm{ft}$ outside the southeastern boundary of the study area. The Shinarump ranges from 15 to $35 \mathrm{ft}$ in thickness near the mine portal. Mine workings were driven southwestward for about $5,600 \mathrm{ft}$ following the N. $25^{\circ} \mathrm{E}$. trend of the Blue Lizard-Markey paleochannel (pl. 1). More than $20,000 \mathrm{ft}$ of mine workings were dug including the main drift, side drifts, and cross cuts; about $1,600 \mathrm{ft}$ of workings are beneath the easternmost prong of the wilderness study area. Ore zones (more than $5 \mathrm{ft}$ thick) averaging 0.15 percent $\mathrm{U}_{3} \mathrm{O}_{8}$ are 1,700 to $4,400 \mathrm{ft}$ from the portal and are generally elongate paralleling the paleochannel trend. The largest ore zone, outside the study area, is about $600 \mathrm{ft}$ long and $200 \mathrm{ft}$ wide. The paleochannel may trend southwestward beneath the wilderness study area and Moqui Canyon. Exploratory drilling defined sandstone of the Shinarump more than $30 \mathrm{ft}$ thick containing between 0.01 and less than 0.05 percent $\mathrm{U}_{3} \mathrm{O}_{8}$ in the $\mathrm{SW}^{1 / 4} 4$ sec. 36 , T. 37 S., R. 14 E. (Calvin Black, mine owner, unpub. data, 1988).

From 1956 to 1965 , the White Canyon district produced approximately 1,000,000 short tons of uranium ore, 40 percent of which was from the Red Canyon area (Doelling, 1969). Twenty-nine uranium deposits occur in the Red Canyon area. All but two of the deposits are less than 50,000 tons, and none exceeds 500,000 tons (Malan, 1968). The Markey mine was probably the largest producer in the Red Canyon area, and as of mid-1967, total production was more than 200,000 pounds $\mathrm{U}_{3} \mathrm{O}_{8}$. Production from the Blue Lizard and Posey mines totaled more than 20,000 pounds but less than 200,000 pounds $\mathrm{U}_{3} \mathrm{O}_{8}$ (Hackman and Wyant, 1973).

Finely disseminated gold in rock ranging from claystone to coarse-grained sandstone of Permian to Jurassic age is known to occur at a few localities on the Colorado Plateau (Butler and others, 1920). These rocks (Cutler, Moenkopi, Chinle, and Kayenta Formations) are exposed in and near the study area. The reported gold occurrences nearest to the study area are about $15 \mathrm{mi}$ south in sandstone along the San Juan River and about $10 \mathrm{mi}$ northwest in Triassic sandstone near the Henry Mountains. Gold values ranged from 0.3 to $1.5 \mathrm{ppm}$ or $\$ 0.20$ to $\$ 1.00 /$ ton at $\$ 20.67 /$ troy ounce $(0.01-0.05$ troy ounces/ton) at these localities (Butler and others, 1920).

\section{Oil and Gas}

The Mancos Mesa Wilderness Study Area is on the western flank of the Monument uplift, a Laramide (Late Cretaceous to Eocene) vertical uplift on the western side of the Paradox basin. No oil or gas have been produced from Mancos Mesa and vicinity. Oil and gas production within the Paradox basin has been primarily from bioherms (moundlike mass of rock built up by sedentary marine organisms) and structural traps within carbonate rocks of the Middle and Upper Pennsylvanian Hermosa Formation, although minor production has been from Permian and Triassic rocks (Irwin and others, 1980). These rocks underlie the Mancos Mesa Wilderness Study Area but have not been thoroughly tested. More than half of the study area is leased for oil and gas (fig. 2), and oil and gas drilling has taken place in the study area. Amoco Production Co. drilled a well (Mancos Mesa No. 1-B) in SE $1 / 4 \mathrm{SE}^{1 / 4} 4$ sec. 2, T. 37 S., R. 13 E. (pl. 1 and fig. 2) that was plugged and abandoned in December 1987. The well, which was spudded in the Navajo Sandstone, was drilled to test the Lower Permian White Rim Sandstone Member of the Cutler Formation. According to T.E. Dill of Amoco (written commun., 1988), the well was drilled to a depth of $2,216 \mathrm{ft}$ and bottomed in the Organ Rock Tongue of the Cutler Formation; the White Rim Sandstone Member was absent.

Three dry oil and gas holes are just outside (less than $2 \mathrm{mi}$ ) the southern and eastern boundaries of the wilderness study area (pl. 1 and fig. 2). The southern well (Southland Royalty Co. No. 1 Moqui Canyon), spudded in the Kayenta Formation in 1980, was drilled to a depth of $6,031 \mathrm{ft}$ and bottomed in Devonian rocks. One of the eastern wells (Southland Royalty Co. No. 1 Red Canyon), also drilled in 1980, spudded in the Chinle Formation and penetrated $4,600 \mathrm{ft}$ of strata and bottomed in Mississippian rocks. The other eastern well (Texota Oil Co. No. 1-X Moqui Federal), drilled in 1962, also spudded in the Chinle Formation, penetrated 5,060 $\mathrm{ft}$ of strata and bottomed in Devonian rocks (BLM well records, Moab, Utah).

\section{Sand, Gravel, and Stone}

Extensive sand, gravel, and stone occurrences in the study area are probably suitable for many construction purposes; however, transportation costs for these high-bulk and low-unit-value commodities would push total production costs far beyond their current market value, and they are not classified as an identified resource. Adequate material is available closer to existing markets in the region. Near Utah State Highway 263 , south of the study area, a few playa-lake dolostonelimestone lenses within the Lower Jurassic Navajo 


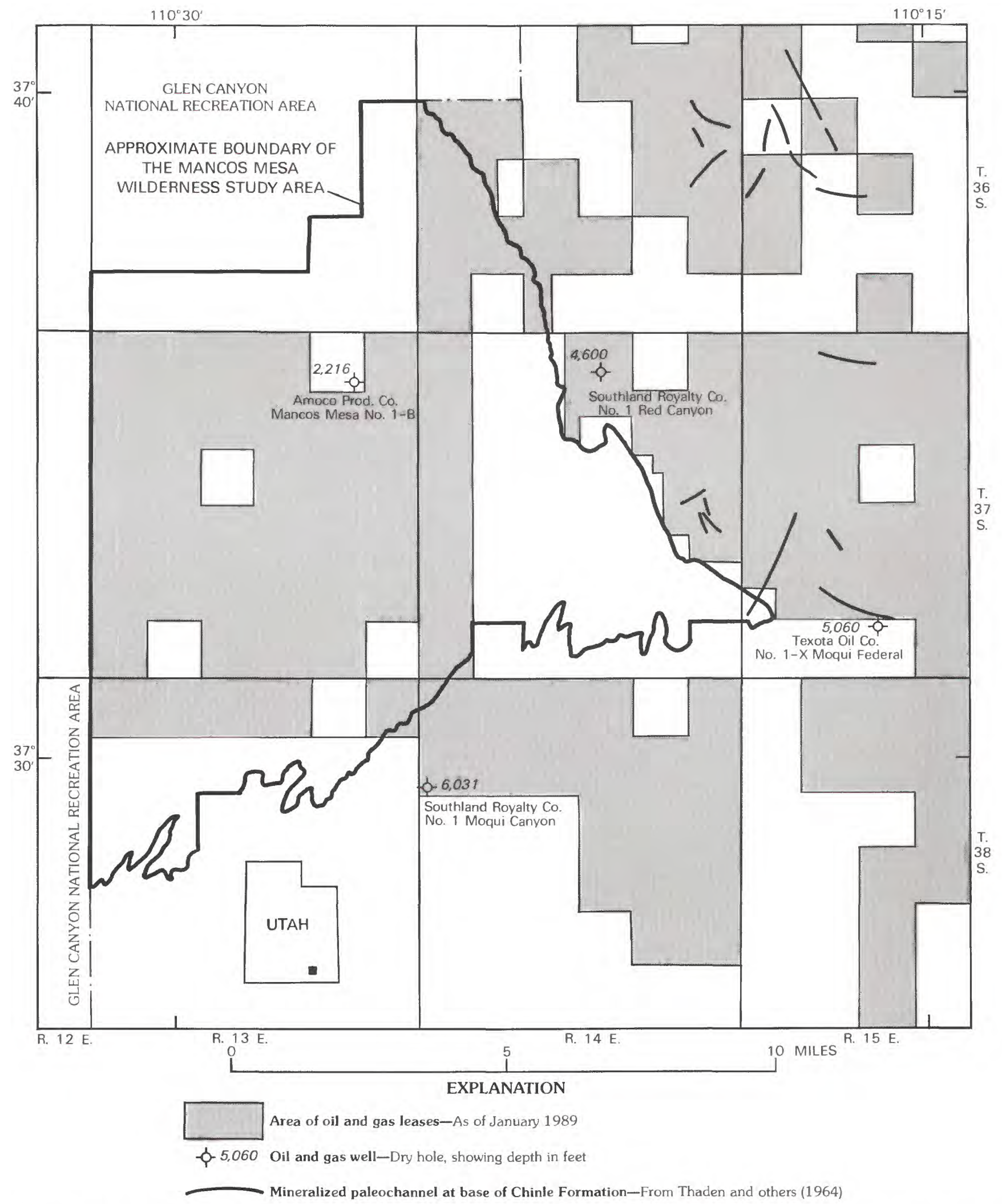

Figure 2. Oil and gas leases and wells, and mineralized paleochannels in the Mancos Mesa Wilderness Study Area, San Juan County, Utah. 
Sandstone (pl. 1) were quarried and presumably used locally for highway construction material.

\section{ASSESSMENT OF POTENTIAL FOR UNDISCOVERED RESOURCES}

By Forrest G. Poole, George A. Desborough, Harlan N. Barton, William F. Hanna, and Keenan Lee

U.S. Geological Survey

\section{Geology}

Mancos Mesa is on the gently dipping western flank (so-called "White Canyon slope") of the northtrending Monument uplift (fig. 1), a Laramide regional elongate structure about $90 \mathrm{mi}$ long and about $30 \mathrm{mi}$ wide. Maximum structural relief is about $4,000 \mathrm{ft}$ (Kelley, 1958). The eastern flank of the uplift is formed by steeply eastward dipping rocks of Comb Ridge, a monocline that separates the uplift from the Blanding basin farther east. Mancos Mesa and vicinity is underlain by a gently west dipping $\left(1-4^{\circ}\right)$ homoclinal section of Cambrian to Jurassic sedimentary rocks. The oldest exposed rocks are on the eastern side of the mapped area, and the youngest are on the western side (pl. 1). The wide western flank of the Monument uplift descends gently and uniformly into the Henry basin to the west (fig. 1). The oldest rocks exposed in the wilderness study area comprise the Upper Triassic Chinle Formation consisting of fluvial and lacustrine mudstone, siltstone, sandstone, conglomerate, and minor limestone. The Chinle Formation is overlain by the Lower Jurassic Glen Canyon Group that, in ascending order, includes the Wingate Sandstone composed predominantly of eolian sandstone, the Kayenta Formation composed of fluvial and lacustrine sandstone, siltstone, conglomeratic sandstone, and minor eolian sandstone in the upper part, and the Navajo Sandstone composed of eolian sandstone and thin beds of playa-lake limestone and dolostone. The Middle Jurassic Carmel Formation, which overlies the Navajo Sandstone, is the youngest formation in the study area. It consists of near-shore marginal-marine sandstone, siltstone, and mudstone. Only the lower part of the Carmel is preserved in the study area where it caps a few small mesas and buttes.

The main geologic structures in the wilderness study area consist of joints and high-angle faults of relatively small displacement that trend northeast, north, and northwest (pl. 1). Joints are nearly vertical and are most conspicuous in the well-cemented sandstone units of the Glen Canyon Group. Some of the fractures mapped as joints have minor displacement. The mapped high-angle faults have measurable stratigraphic offsets within the sedimentary rocks. Fault displacements were determined from aerial photographs by measuring the distance between correlative beds on opposite sides of faults with a digitized photogrammetric instrument (Kern PG 2). Offsets are shown on the geologic map (pl. 1). Measured fault displacements in the study area range from a few feet to as much as $235 \mathrm{ft}$. Dips of beds locally become gentler or reverse direction on the downthrown sides of major faults indicating rotation of the downdropped block. Many of the faults and joints are filled with calcite.

\section{Geochemistry}

Eighty-two rock samples were collected from outcrops of Triassic and Jurassic strata during geologic mapping of the Mancos Mesa Wilderness Study Area. Semiquantitative spectrographic analyses for 35 elements were obtained on all samples; analyses by flame atomic absorption for gold and a fluorometric technique for uranium were obtained on 64 siliciclastic rock samples. Analytical methods are described in Baedecker (1987). No anomalous gold concentrations were detected in the samples collected in the study area (detection limit 0.05 $\mathrm{ppm}$ ). Fourteen (22 percent) of the siliciclastic samples contained anomalous uranium. Analyses of outcrop samples indicate slightly anomalous concentrations of arsenic, barium, beryllium, boron, cadmium, calcium, cobalt, copper, gallium, iron, lanthanum, lead, magnesium, manganese, molybdenum, nickel, phosphorus, scandium, selenium, silver, sodium, strontium, titanium, uranium, vanadium, yttrium, zinc, and zirconium in as many as 19 (less than 1 to 23 percent) of the 82 samples. In general, elemental abundances in most of the samples are similar to the average abundances in unaltered sandstone, shale, and carbonate rocks (Turekian and Wedepohl, 1961). However, barium, manganese, and lead values in 14 of the samples representing all the Triassic and Jurassic formations in the study area are high relative to average unaltered sedimentary rocks. Seven mineralized samples of sandstone from the Shinarump Member of the Chinle Formation at the Posey uranium mine in Red Canyon ( $1 \mathrm{mi}$ east of the wilderness study area boundary) have metal concentrations as much as $380 \mathrm{ppm}$ (parts per million) arsenic, 1,000 ppm barium, $15 \mathrm{ppm}$ beryllium, $1 \mathrm{ppm}$ cadmium, $500 \mathrm{ppm}$ cobalt, more than 2 percent copper, 15 percent iron, 70 ppm lanthanum, $50 \mathrm{ppm}$ lead, 1,000 ppm manganese, 20 ppm molybdenum, $150 \mathrm{ppm}$ nickel, $30 \mathrm{ppm}$ silver, 1 percent titanium, $680 \mathrm{ppm}$ uranium, $200 \mathrm{ppm}$ vanadium, $200 \mathrm{ppm}$ yttrium, 1,000 ppm zinc, and 1,000 ppm zirconium (Bullock and others, in press). The principal pathfinder elements associated with sandstone-type uranium deposits in this region are copper, lead, 
molybdenum, selenium, silver, vanadium, and zinc (Levinson, 1980; Kness, 1987).

Stream-sediment samples and the nonmagnetic fraction of heavy-mineral-concentrate samples panned from stream sediments were collected for geochemical analysis. A total of 36 stream-sediment samples and 36 panned-concentrate samples were analyzed using semiquantitative emission spectrography as described by Golightly and others (1987). Mineralogic identification of the heavy-mineral fraction of the panned-concentrate samples was also made. Three or more of five streamsediment samples collected in Red Canyon between a locality near the No. 1 Red Canyon drill site and a locality $0.5 \mathrm{mi}$ northwest of the Markey mine (pl. 1) have slightly anomalous concentrations of barium, boron, cadmium, cobalt, copper, iron, lead, magnesium, manganese, nickel, niobium, scandium, strontium, titanium, vanadium, zinc, and zirconium, compared to average sandstone (Turekian and Wedepohl, 1961). One or more of five heavy-mineral-concentrate samples from the same sites have anomalous concentrations of barium, copper, gold, iron, lanthanum, lead, manganese, molybdenum, niobium, silver, strontium, and tin. Barite was identified in all samples. Although these anomalous samples are from Red Canyon just east of the wilderness study area boundary, they consist of detrital material derived mainly from the Chinle Formation that also underlies Mancos Mesa. A sample locality map and a list of the geochemical data are in Bullock and others (in press).

\section{Geophysics}

\section{Aeromagnetic and Gravity Data}

An aeromagnetic survey (fig. 3) of the study area was made based on total-field measurements made by the U.S. Geological Survey (Case and Joesting, 1972) along 17 east-west traverses flown approximately $1 \mathrm{mi}$ apart at an average elevation of $8,500 \mathrm{ft}$. Regional gravity anomaly data, reduced by using a density of 2.67 grams per cubic centimeter, considered to be average in this report, are available in the form of a simple (not corrected for terrain) Bouguer gravity anomaly map (Cook and others, 1975). A region of small-amplitude gravity lows shown on this map is outlined on figure 3 for comparison with the magnetic anomalies. General knowledge of rock magnetization and density is based on data of Case and Joesting (1972), Case (1966), and Joesting and Byerly (1956). Data for Precambrian basement rocks were extrapolated from measurements of exposed basement in the Uncompahgre uplift (Case, 1966), about $125 \mathrm{mi}$ northeast of the study area.

Prominent magnetic anomalies within and near the study area mainly reflect compositional and structural trends of Precambrian basement rocks (Case and Joest- ing, 1972). Two magnetic lows M1, which are within the region of gravity lows, probably reflect basement rocks that are nonmagnetic or reversely magnetized and of lower than average density. The anomaly source is inferred to be nonmagnetic quartzite, argillite, or quartzofeldspathic gneiss. Magnetic high M2, which is also within the region of gravity lows, is inferred to have a source similar in density to the source of M1 but stronger in total magnetization. Such a source could be quartz monzonite. Magnetic highs M3, M4, and M5 have magnetic sources that are average or above average in density as evidenced by the presence of the highs in a region of higher Bouguer gravity anomalies. Sources of these highs are probably mafic basement rocks, such as metadiorite or metagabbro. Alternatively, because these highs lie approximately on strike with a northwesttrending zone of laccolithic intrusions extending into the Henry Mountains $15 \mathrm{mi}$ to the northwest (Case and Joesting, 1972), their sources may be buried Laramide intrusive rocks, such as diorite porphyry. For example, the small circular high M5 is similar in wavelength to, but lower in amplitude than, highs over laccolithic intrusions in or near the Henry Mountains. If M5 has a source similar to those in the Henry Mountains area, its smaller amplitude could be explained by its greater depth of burial, and its northwest finger-shaped extension could be explained by a narrow intrusion along a northwesttrending basement-fracture zone. The source of magnetic low M6, immediately northwest of high M4, is unknown. This feature may be a polarization low associated with magnetic high M4, provided the source rock has anomalously directed magnetization. More likely, the low may reflect nonmagnetic but dense gneissic granodiorite or amphibolite exposed in the Uncompahgre uplift (Case, 1966).

The straightness and closeness of contours flanking the various magnetic features suggest that the basement underlying the study area is composed of compositionally distinct blocks which are bounded by steep discontinuities presumed to be faults. This polygonal geometry of the Precambrian basement, manifested widely by steep, linear gradients of both magnetic and gravity anomalies, was inferred by Case and Joesting (1972) to extend throughout much of the central Colorado Plateau.

\section{Remote-Sensing Data}

The wilderness study area was included within a regional remote-sensing investigation of eastern Utah and western Colorado (Lee, 1987). Remote-sensing data for the study area were obtained from Landsat Multispectral Scanner images for lineament analysis and Landsat Thematic Mapper imagery data for limonite anomalies. We evaluated lineaments, along with geophysical and deep-drilling data, to make inferences about 


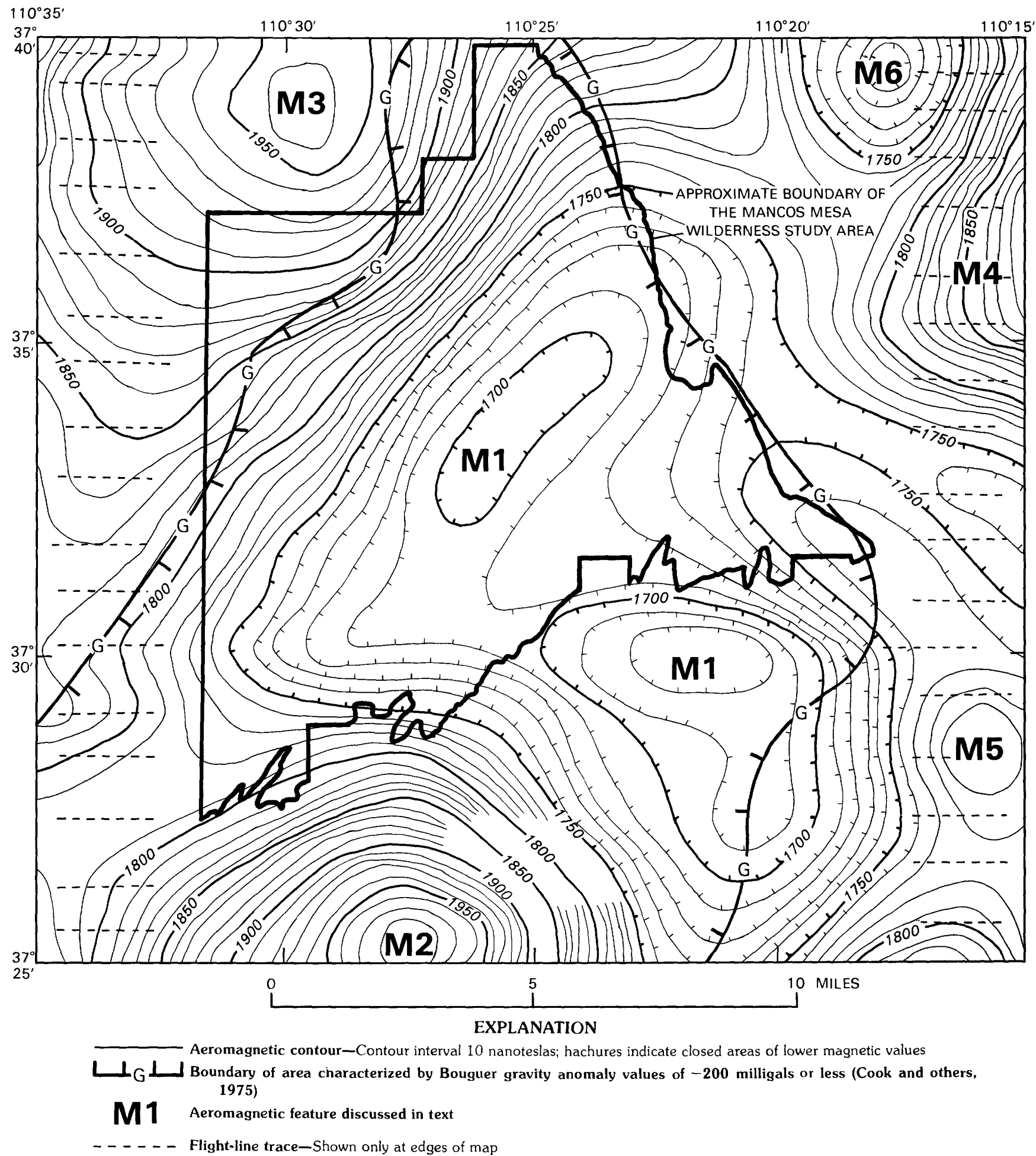

Figure 3. Aeromagnetic anomaly map of the Mancos Mesa Wilderness Study Area, Utah. From Case and Joesting (1972).

basement structures. Limonite occurrences can result from hydrothermal alteration associated with mineralization, commonly from surface weathering of pyrite, and reverse limonite anomalies can be associated with either uranium deposition or hydrocarbon seepage.
The absence of limonite (reverse limonite anomaly) within normally limonitic redbeds indicates either possible reducing environments favorable for uranium deposition or redox alteration caused by seeping hydrocarbons. Uranium ions in solution frequently precipitate 
at sites where reductants occur, that is, at sites lacking hematite or goethite. For example, migrating hydrocarbons in the Lower Permian White Rim Sandstone Member in the Elaterite basin, about $25 \mathrm{mi}$ northnortheast of the study area (fig. 1), alter the oxidation state of iron in the enclosing redbeds of the overlying Moenkopi Formation and underlying Organ Rock Tongue of the Cutler Formation. Ferric iron in hematite is reduced to the ferrous state, which allows removal of the iron as aqueous ferrous ion. These areas of alteration can be identified on the thematic mapper images.

Results of the lineament analysis reported in Lee (1987) are shown on figure 1. The Mancos Mesa Wilderness Study Area lies between two parallel, northeast-trending regional lineaments, VL7 and DL1. Visual lineaments VL7 and 7A, east of the study area, correlate well with Bouguer gravity data (Cook and others, 1975; Case and Joesting, 1961, 1972), corresponding to truncations of northwest-trending anomalies. They correlate only weakly with aeromagnetic data (Case and Joesting, 1961, 1972), coinciding with a few small high anomalies. The lineament correlates strongly with surface structures, coinciding with three separate fault systems, including the Quaternary(?) Shay graben about $12 \mathrm{mi}$ northwest of Monticello, Utah (fig. 1). Drainage lineament DL1 is derived mainly from the remarkably straight reach of the Colorado River west of the study area. This lineament extends for about $150 \mathrm{mi}$, offset slightly in a dextral sense just north of the Mancos Mesa Wilderness Study Area. Although this lineament correlates only weakly with gravity and aeromagnetic data, it coincides with a series of extensive basement faults that truncate numerous Precambrian terranes (see map of Case and Joesting, 1972), and forms part of the Colorado Lineament (Warner, 1978). Lineament DL1 may have influenced deposition during late Paleozoic time. The basement structure, probably a fault, may have controlled deposition of the Lower Permian White Rim Sandstone Member, which occurs almost everywhere northwest of the lineament and is absent almost everywhere southeast of the lineament. The White Rim Sandstone Member is absent in Red Canyon and in the Mancos Mesa No. 1-B drill hole on Mancos Mesa (pl. 1 and fig. 2).

Spectral processing of the Landsat Thematic Mapper data to find limonite occurrences possibly indicating hydrothermal alteration led to the identification of several small limonite anomalies in the northwestern part of the study area. Some of these were discounted as small erosional remnants of Jurassic redbeds, and others were interpreted as modern dunes composed of iron-stained sand grains. Reducing environments within the lower part of the Chinle Formation were looked for along the northeastern escarpment of Mancos Mesa on the western side of Red
Canyon, where Shinarump Member channel-fill deposits form favorable sites for copper and uranium deposition. No such reverse limonite anomalies were found, but the nearly vertical exposures of these beds prevented imaging by the satellite sensors.

\section{Aerial Radiometric Data}

Radiometric data for the Mancos Mesa Wilderness Study Area were obtained from a 1:1,000,000-scale map of Utah (J.S. Duval, USGS, unpub. data) produced from data obtained between 1975 and 1983 by contractors working for the U.S. Department of Energy. The survey method used, aerial gamma-ray spectroscopy, is a radiometric technique that provides an estimate of nearsurface (0-20 in. (inches) depth) concentrations of uranium, thorium, and potassium. Detection of anomalous concentrations of these radiogenic elements requires that their concentrations be high relative to background values established for the area studied. Individual measurements made in this and other typical aerial surveys reflect the concentrations of these elements in an area of about 0.02 square mile.

On the basis of several flights flown approximately $400 \mathrm{ft}$ above the ground in an east-west direction and spaced about $3 \mathrm{mi}$ apart, the radioactivity level is low in the entire Mancos Mesa Wilderness Study Area. The aerial radiometric survey indicated values of $0.1-1.5 \mathrm{ppm}$ equivalent uranium, 1-6 ppm thorium, and 0.8-1.6 percent potassium (J.S. Duval, written commun., 1987). This survey identified no significant radioactivity anomalies within the boundaries of the wilderness study area or in the immediate vicinity.

\section{Mineral and Energy Resources}

\section{Uranium}

Uranium deposits are present in the Shinarump Member of the Upper Triassic Chinle Formation just east of the study area. The deposits occur in Shinarump fluvial sandstone and conglomerate that fill stream channels cut into the underlying Lower and Middle(?) Triassic Moenkopi Formation. Shinarump channel-fill sediments at or near the contact with the Moenkopi constitute the most favorable zone for ore deposition. The Blue Lizard-Markey mineralized paleochannel in Red Canyon extends beneath the southeastern edge of the study area (pl. 1 and fig. 2), and other similar-grade sandstone-type uranium deposits characteristic of the region may be present in the Shinarump Member beneath Mancos Mesa. Shinarump paleochannels and trends, shown on plate 1 and figure 2, are from the map of Thaden and others (1964). Only those channels with 
depths of more than $2 \mathrm{ft}$ are shown. A similar spacing and size of Shinarump paleochannels mapped in the Red Canyon area are likely to occur under Mancos Mesa. According to Grundy and Oertell (1958), most of the known uranium deposits in the White Canyon-Red Canyon area are localized within channels in sediments consisting of poorly sorted, medium- to coarse-grained sandstone containing moderate to abundant amounts of carbonaceous material, silt pebbles, clay lenses, and interstitial clay. Finnell and others (1963) suggested that local structures, such as changes in regional dip, may be important in determining both the position of channels and the location of uranium deposits in the channels. No significant ore deposits have been found outside the channels in the White Canyon-Red Canyon area. No optimum width, depth, or ratio of width to depth of channels has been found for the occurrence of uranium ores; however, known commercial deposits occur in channels having depths of more than $4 \mathrm{ft}$ and widths of more than $100 \mathrm{ft}$ (Thaden and others, 1964). The Shinarump fluvial system in the White Canyon-Red Canyon area trends west, and most cross-strata dip directions and channels trend southwest to northwest (Grundy and Oertell, 1958; Johnson and Thordarson, 1959; Poole, 1961; Thaden and others, 1964; Dubiel, 1983; Dubiel and others, 1987). Localization of uranium deposits in the Shinarump by folds and faults has not been perceived (Grundy and Oertell, 1958).

Although the Upper Triassic Chinle Formation does not crop out in the Mancos Mesa Wilderness Study Area, it is exposed in canyons immediately north, east, and south of the boundary (pl. 1). In the north-central part of the study area, at a depth of 1,649-1,684 ft, $35 \mathrm{ft}$ of sandstone of the Shinarump was penetrated in the Amoco Production Co. Mancos Mesa No. 1-B drill hole (T.E. Dill, Amoco, written commun., 1988). In the southeastern part of the study area, many exploratory holes were drilled in 1976-79 by Gulf Mineral Resources Co. to test the uranium content of the Shinarump Member. No information is available on the results of their drilling program. These data, combined with the known uranium occurrences in Red Canyon to the east, indicate that the Mancos Mesa Wilderness Study Area is underlain by the Shinarump fluvial system and has a moderate mineral resource potential for uranium (pl. 1, fig. 1). Minor amounts of copper, vanadium, and other metals such as cobalt, lead, and nickel are associated with uranium deposits in the Shinarump Member in the nearby Red Canyon-White Canyon area. Amoco drilled $35 \mathrm{ft}$ of Shinarump consisting of poorly to well sorted, medium- to coarse-grained sandstone containing carbonaceous material and pyrite. Because of the uncertain presence and location of subsurface Shinarump paleochannel systems beneath Mancos Mesa, the mineral resource potential for uranium in this area is moderate. The area of moderate mineral resource potential for uranium is assigned a certainty level of $\mathrm{C}$ (pl. 1, fig. 1), based on the known uranium deposits in adjacent areas, the occurrence of similar host rocks beneath the study area, and the more uncertain projection of trends favorable for the formation of uranium deposits into the study area based on models developed in this study. However, high exploration costs for concealed deposits makes it unlikely that many deposits will ever be discovered in the Shinarump Member under Mancos Mesa, as the Shinarump is buried more than $1,000 \mathrm{ft}$ under the wilderness study area.

Minor occurrences of metals that are intimately associated with uranium deposits are discussed in the following section.

\section{Metals Other Than Uranium}

Base- (copper, lead, zinc, molybdenum, and related metals) and precious- (silver, gold, and platinum-group) metal deposits in the Western United States commonly are associated with igneous plutons. No igneous intrusive rocks have been recognized in the Mancos Mesa Wilderness Study Area.

Within the Mancos Mesa Wilderness Study Area, no mining for metals has taken place, and there are no known occurrences of significant metal deposits other than uranium. Mineralized rock associated with Shinarump Member paleochannels in Red Canyon just east of the study area contains minor copper deposits. The Mancos Mesa Wilderness Study Area is considered to have a low mineral resource potential for base and precious metals. This low mineral resource potential is assigned a certainty level of $\mathrm{C}$, based on the known geologic and geochemical data bases.

\section{Oil and Gas}

Oil and gas have been produced from Devonian, Mississippian, Pennsylvanian, Permian, and Triassic rocks in the Paradox basin area of southeastern Utah (Ritzma, 1969). Most of these strata are known to occur in the subsurface near the wilderness study area. The possibility of oil and gas generation from Pennsylvanian organic-rich shale in the subsurface is enhanced by organic geochemical data from a 1-in.-thick coaly mudstone layer (42 percent total organic carbon) in the lower part (Monitor Butte Member) of the Chinle Formation $1,000 \mathrm{ft}$ southeast of the No. 1 Red Canyon drill hole (pl. 1). Vitrinite reflectance $\left(R_{o}\right.$; mean random value, 0.6 percent) measured on the coaly sample indicates marginally mature humic kerogen (Mark Pawlewicz, USGS, written commun., 1988), a stage of organic maturity that corresponds to the onset of oil generation. 
Therefore, any organic-rich rock capable of producing oil or gas that is deeply buried beneath Mancos Mesa should generate hydrocarbons in that higher heat-flux environment. In southeastern Utah, the Mississippian Leadville Limestone, which underlies the wilderness study area, is a suitable oil and gas reservoir rock but a poor source rock due to the absence of organic shale. Pennsylvanian organic reefs are known to be reservoir rocks in the Blanding basin east of the Monument uplift. These reefs grew along the shelf margins of the Pennsylvanian Paradox basin and may be present at depth beneath the study area. Pennsylvanian rocks are exposed about $15 \mathrm{mi}$ south of the study area in the San Juan River canyon; thus, reservoir pressures over a large area including the study area may have been lowered, and oil potential may be decreased (Irwin and others, 1980).

On the Monument uplift, oil shows have been reported in the Mississippian Leadville Limestone, Middle and Upper Pennsylvanian Hermosa Formation, and Lower Permian Cedar Mesa Sandstone and White Rim Sandstone Members of the Cutler Formation. Oil occurrences also have been reported in the Pennsylvanian Honaker Trail Formation (Clem and Brown, 1984).

The Tar Sand Triangle oil-impregnated sandstone deposit is about $25-45 \mathrm{mi}$ northeast of the study area. The deposit covers about 200 square miles and contains as much as 16 billion barrels of heavy oil (Campbell and Ritzma, 1979). The stratigraphic traps were interpreted by Baars and Seager (1970) to be marine sand bars formed by thinning and updip facies change of the Lower Permian White Rim Sandstone Member and the Organ Rock Tongue (shale) of the Cutler Formation. The White Rim Sandstone Member has not been recognized in the oil and gas exploratory holes drilled in the wilderness study area or just east and south of the study area boundary. Therefore, if the White Rim is present in the study area, it would be under the unexplored western part. The updip pinchout of the White Rim on the western flank of the Monument uplift may form a stratigraphic trap for migrating oil and gas.

Owing to the possibility of Pennsylvanian carbonate-mound reservoirs at depth, the Mancos Mesa Wilderness Study Area is assessed as having a moderate energy resource potential for oil and gas, based on stratigraphic and structural setting, inferred petroleum source rocks, and thermal history. A certainty level of C is assigned, based on the regional geology and occurrence of possible hydrocarbon-bearing units at depth below the study area coupled with a lack of knowledge of the exact subsurface distribution of these rocks and their hydrocarbon content.
Coal

No coal was found in the Mancos Mesa Wilderness Study Area. Thin (less than 1 in.) lenses of coaly mudstone occur in the lower part of the Chinle Formation in Red Canyon, but these occurrences are not considered coal resources. No economic coal deposits are known to occur in Permian to Jurassic strata of the Colorado Plateau, and no coal was reported in drilling records for the four wells penetrating these strata in the study area and vicinity. Therefore, the potential for coal resources in the wilderness study area is low, with level C certainty.

\section{Geothermal Energy}

The absence of thermal springs in Mancos Mesa and adjacent areas indicates that the potential for geothermal resources in the study area is low, with level C certainty.

\section{REFERENCES CITED}

Baars, D.L., and Seager, W.R., 1970, Stratigraphic control of petroleum in White Rim Sandstone (Permian) in and near Canyonlands National Park, Utah: American Association of Petroleum Geologists Bulletin, v. 54, no. 5, p. 709-718.

Baedecker, P.A., ed., 1987, Methods for geochemical analysis: U.S. Geological Survey Bulletin 1770, 132 p.

Bullock, J.H., Jr., Barton, H.N., and others, in press, Analytical results and sample locality map of stream-sediment, heavy-mineral concentrate, and rock samples from Mancos Mesa Wilderness Study Area (UT-060-181), San Juan County, Utah: U.S. Geological Survey Open-File Report 89-438.

Butler, B.S., Loughlin, G.F., Heikes, V.C., and others, 1920, The ore deposits of Utah: U.S. Geological Survey Professional Paper 111, 672 p.

Campbell, J.R., and Ritzma, H.R., 1979, Geology and petroleum resources of the major oil-impregnated sandstone deposits of Utah: Utah Geological and Mineralogical Survey Special Studies 50, 24 p.

Case, J.E., 1966, Geophysical anomalies over Precambrian rocks, northwestern Uncompahgre Plateau, Utah and Colorado: American Association of Petroleum Geologists Bulletin, v. 50, no. 7, p. 1423-1443.

Case, J.E., and Joesting, H.R., 1961, Precambrian structures in the Blanding basin and Monument upwarp, southeast Utah, in Short papers in the geologic and hydrologic sciences: U.S. Geological Survey Professional Paper 424-D, p. D287-D291.

1972, Regional geophysical investigations in the central Colorado Plateau: U.S. Geological Survey Professional Paper 736, $31 \mathrm{p}$.

Chenoweth, W.L., 1975, Uranium deposits of the Canyonlands area, in Fassett, J.E., ed., Canyonlands country: Four Corners Geological Society, Eighth Field Conference, Guidebook, p. 253-260. 
Clem, K.M., and Brown, K.W., 1984, Petroleum resources of the Paradox basin: Utah Geological and Mineral Survey Bulletin 119, 162 p.

Cook, K.L., Montgomery, J.R, Smith, J.T., and Gray, E.F., 1975, Simple Bouguer gravity anomaly map of Utah: Utah Geological and Mineral Survey Map 37, scale $1,000,000$.

Doelling, H.H., 1969, Mineral resources, San Juan County, Utah, and adjacent areas; Part II, Uranium and other metals in sedimentary host rocks: Utah Geological and Mineralogical Survey Special Studies 24, 64 p.

Dubiel, R.F., 1983, Sedimentology of the lower part of the Upper Triassic Chinle Formation and its relationship to uranium deposits, White Canyon area, southeastern Utah: U.S. Geological Survey Open-File Report 83-459, $47 \mathrm{p}$.

Dubiel, R.F., Bromfield, C.S., Church, S.E., Kemp, W.M., Larson, M.J., Peterson, Fred, Pierson, C.T., and Kreidler, T.J., 1987, Mineral resources of the Little Rockies Wilderness Study Area, Garfield County, Utah: U.S. Geological Survey Bulletin 1751-A, p. A1-A11.

Finnell, T.L., Franks, P.C., and Hubbard, H.A., 1963, Geology, ore deposits, and exploratory drilling in the Deer Flat area, White Canyon district, San Juan County, Utah: U.S. Geological Survey Bulletin 1132, 114 p.

Golightly, D.W., Dorrzapf, A.F., Jr., Mays, R.E., Fries, T.L., and Conklin, N.M., 1987, Analysis of geologic materials by direct-current arc emission spectrography and spectrometry, in Baedecker, P.A., ed., Methods for geochemical analysis: U.S. Geological Survey Bulletin 1770, p. A1-A13.

Goudarzi, G.H., 1984, Guide to preparation of mineral survey reports on public lands: U.S. Geological Survey OpenFile Report 84-787, 42 p.

Grundy, W.D., and Oertell, E.W., 1958, Uranium deposits in the White Canyon and Monument Valley mining districts, San Juan County, Utah, and Navajo and Apache Counties, Arizona, in Sanborn, A.F., ed., Guidebook to the geology of the Paradox Basin: Intermountain Association of Petroleum Geologists, Ninth Annual Field Conference, Guidebook, p. 197-207.

Hackman, R.J., and Wyant, D.G., 1973, Geology, structure, and uranium deposits of the Escalante quadrangle, Utah and Arizona: U.S. Geological Survey Miscellaneous Geologic Investigations Series Map I-744, scale 1:250,000.

Irwin, C.D., Clark, W.R., and Peabody, W.W., 1980, Petroleum geology of Henry Mountains basin, in Picard, M.D., ed., Henry Mountains symposium: Utah Geological Association Publication 8, p. 353-366.

Joesting, H.R., and Byerly, P.E., 1956, Aeromagnetic and gravity profiles across the Uravan area, Colorado, in Peterson, J.A., ed., Geology and economic deposits of east-central Utah: Intermountain Association of Petroleum Geologists, Seventh Annual Field Conference, Guidebook, p. 38-41.

Johnson, H.S., Jr., and Thordarson, W., 1959, The Elk RidgeWhite Canyon channel system, San Juan County, Utah; its effect on uranium distribution: Economic Geology, v. 54 , no. 1 , p. 119-129.
Kelley, V.C., 1958, Tectonics of the region of the Paradox basin, in Sanborn, A.F., ed., Guidebook to the geology of the Paradox Basin: Intermountain Association of Petroleum Geologists, Ninth Annual Field Conference, Guidebook, p. 31-38.

Kness, R.F., 1987, Mineral investigation of a part of the Steep Creek Wilderness Study Area (UT-040-061), Garfield County, Utah: U.S. Bureau of Mines Open-file Report MLA 21-87, 36 p.

1988, Mineral investigation of the Mancos Mesa Wilderness Study Area (UT-060-181), San Juan County, Utah: U.S. Bureau of Mines Open-file Report MLA 45-88, 24 p.

Lee, Keenan, 1987, Remote sensing study in support of mineral resource appraisal of the Black Ridge Canyons and Black Ridge Canyons West Wilderness Study Areas, Mesa County, Colorado, and Grand County, Utah, and the Westwater Canyon Wilderness Study Area, Grand County, Utah: U.S. Geological Survey Open-file Report $87-435,10 \mathrm{p}$.

Levinson, A.A., 1980, Introduction to exploration geochemistry: Wilmette, Ill., Applied Publishing, 924 p.

Malan, R.C., 1968, The uranium mining industry and geology of the Monument Valley and White Canyon districts, Arizona and Utah, in Ridge, J.D., ed., Ore deposits of the United States, 1933-1967: American Institute of Mining, Metallurgical, and Petroleum Engineers, Inc., v. 1, Graton-Sales volume, p. 790-804.

Molenaar, C.M., and Sandberg, C.A., 1983, Petroleum potential of wilderness lands in Utah, in Miller, B.M., ed., Petroleum potential of wilderness lands in the western United States: U.S. Geological Survey Circular 902-K, p. K1-K14.

Mullens, T.E., 1960, Geology of the Clay Hills area, San Juan County, Utah: U.S. Geological Survey Bulletin 1087-H, p. 259-336.

Poole, F.G., 1961, Stream directions in Triassic rocks of the Colorado Plateau, in Short papers in the geological sciences: U.S. Geological Survey Professional Paper 424-C, p. C139-C141.

Ritzma, H.R., 1969, Petroleum in the San Juan project area, Utah and Colorado, in Ritzma, H.R., and Doelling, H.H., Mineral resources, San Juan County, Utah, and adjacent areas, part I; Petroleum, potash, ground water, and miscellaneous minerals: Utah Geological and Mineralogical Survey Special Studies 24, p. 9-15.

Science Applications, Inc., 1982, Mineral resource evaluation of Mancos Mesa Wilderness Study Area administered by the Bureau of Land Management: U.S. Department of Energy, Oak Ridge, Tennessee, 15 p., available from U.S. Bureau of Land Management, Moab District Office, 82 E. Dogwood, P.O. Box 970, Moab, Utah 84532.

Thaden, R.E., Trites, A.F., Jr., and Finnell, T.L., 1964, Geology and ore deposits of the White Canyon area, San Juan and Garfield Counties, Utah: U.S. Geological Survey Bulletin 1125,166 p.

Turekian, K.K., and Wedepohl, K.H., 1961, Distribution of the elements in some major units of the Earth's crust: Geological Society of America Bulletin, v. 72, no. 2, p. 175-191. 
U.S. Bureau of Mines and U.S. Geological Survey, 1980, Principles of a resource/reserve classification for minerals: U.S. Geological Survey Circular 831, 5 p.
Warner, L.A., 1978, The Colorado lineament; a middle Precambrian wrench fault system: Geological Society of America Bulletin, v. 89, no. 2, p. 161-171. 
APPENDIX 


\section{DEFINITION OF LEVELS OF MINERAL RESOURCE POTENTIAL AND CERTAINTY OF ASSESSMENT}

\section{LEVELS OF RESOURCE POTENTIAL}

$\mathrm{H}$ HICH mineral resource potential is assigned to areas where geologic, geochemical, and geophysical characteristics indicate a geologic environment favorable for resource occurrence, where interpretations of data indicate a high degree of likelihood for resource accumulation, where data support mineral-deposit models indicating presence of resources, and where evidence indicates that mineral concentration has taken place. Assignment of high resource potential to an area requires some positive knowledge that mineral-forming processes have been active in at least part of the area.

$M$ MODERATE mineral resource potential is assigned to areas where geologic, geochemical, and geophysical characteristics indicate a geologic environment favorable for resource occurrence, where interpretations of data indicate reasonable likelihood for resource accumulation, and (or) where an application of mineral-deposit models indicates favorable ground for the specified type(s) of deposits.

L LOW mineral resource potential is assigned to areas where geologic, geochemical, and geophysical characteristics define a geologic environment in which the existence of resources is permissive. This broad category embraces areas with dispersed but insignificantly mineralized rock, as well as areas with little or no indication of having been mineralized.

N NO mineral resource potential is a category reserved for a specific type of resource in a well-defined area.

$U$ UNKNOWN mineral resource potential is assigned to areas where information is inadequate to assign a low, moderate, or high level of resource potential.

\section{LEVELS OF CERTAINTY}

A Available information is not adequate for determination of the level of mineral resource potential.

B Available information only suggests the level of mineral resource potential.

C Available information gives a good indication of the level of mineral resource potential.

D Available information clcarly defines the level of mineral resource potential.

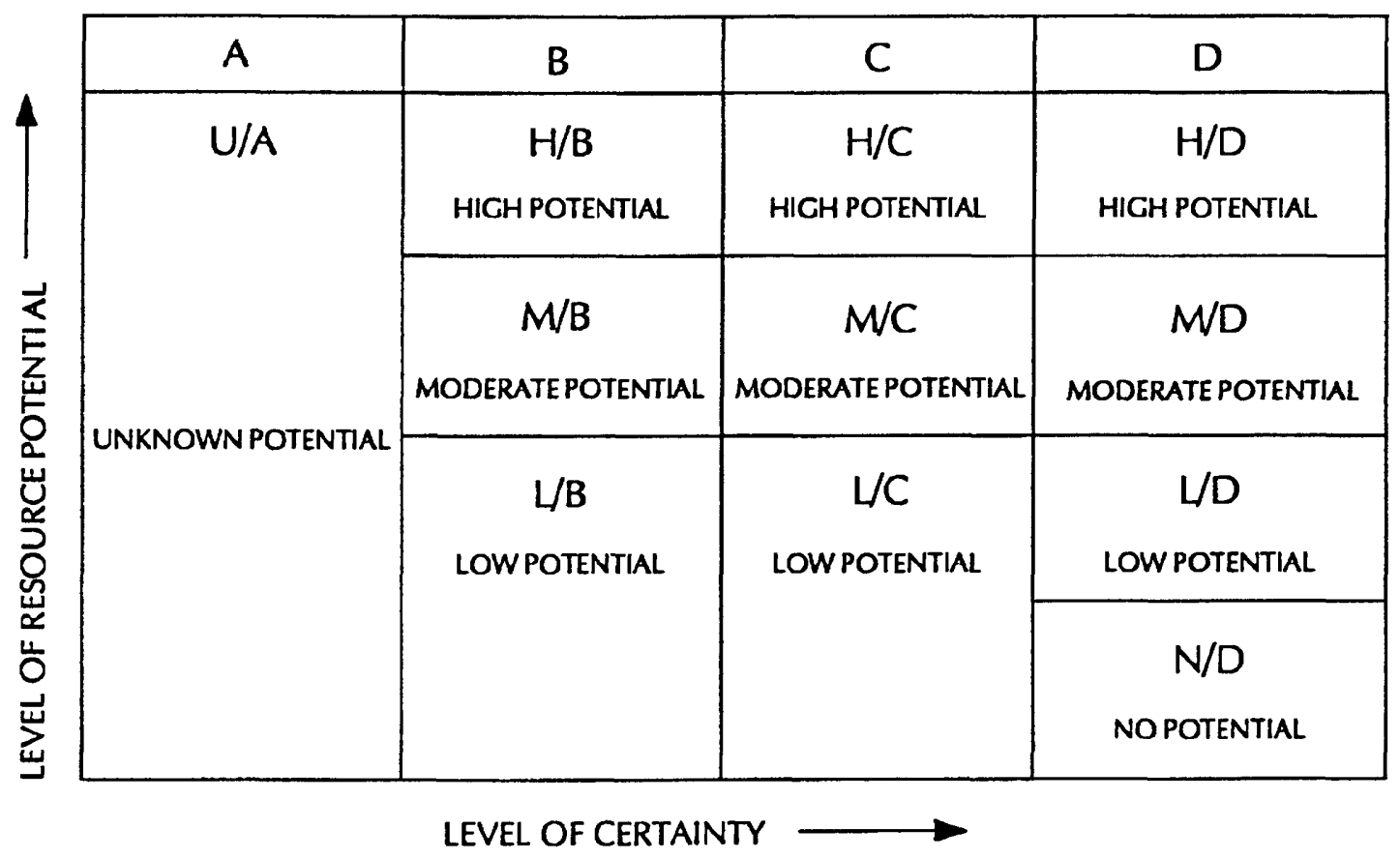

Abstracted with minor modifications from:

Taylor, R.B., and Steven, T.A., 1983, Definition of mineral resource potential: Economic Ceology, v. 78, no. 6, p. $1268-1270$.

Taylor, R.B., Stoneman, R.J., and Marsh, S.F., 1984, An assessment of the mineral resource potential of the San tsabel National Forest, south-central Colorado: U.S. Geological Sunvey Bulletin 1638, p. 40-42.

Coudarzi, G.H., compiler, 1984, Guide to preparation of mineral survey reports on public lands: U.S. Ceological Survey Open-File Report 84-0787, p. 7, 8. 
RESOURCE/RESERVE CLASSIFICATION

\begin{tabular}{|c|c|c|c|c|c|}
\hline & \multicolumn{3}{|c|}{ IDENTIFIED RESOURCES } & \multicolumn{2}{|c|}{ UNDISCOVERED RESOURCES } \\
\hline & \multicolumn{2}{|c|}{ Demonstrated } & \multirow{2}{*}{ Inferred } & \multicolumn{2}{|c|}{ Probability Range } \\
\hline & Measured & Indicated & & Hypothetical & Speculative \\
\hline ECONOMIC & Res & & Inferred Reserves & & \\
\hline $\begin{array}{l}\text { MARGINALLY } \\
\text { ECONOMIC }\end{array}$ & Margine & Reserves & $\begin{array}{c}\text { Inferred } \\
\text { Marginal Reserves }\end{array}$ & & \\
\hline $\begin{array}{c}\text { SUB- } \\
\text { ECONOMIC }\end{array}$ & $\begin{array}{r}\text { Demo } \\
\text { Subeconon }\end{array}$ & $\begin{array}{l}\text { rated } \\
\text { Resources }\end{array}$ & $\begin{array}{l}\text { Inferred } \\
\text { Subeconomic } \\
\text { Resources }\end{array}$ & & \\
\hline
\end{tabular}

Major elements of mineral resource classification, excluding reserve base and inferred reserve base. Modified from McKelvey, 1972, Mineral resource estimates and public policy: American Scientist, v.60, p.32-40, and U.S. Bureau of Mines and U.S. Geological Survey, 1980, Principles of a resource/reserve classification for minerals: U.S. Geological Survey Circular 831, p.5. 
GEOLOGIC TIME CHART

Terms and boundary ages used by the U.S. Geological Survey in this report

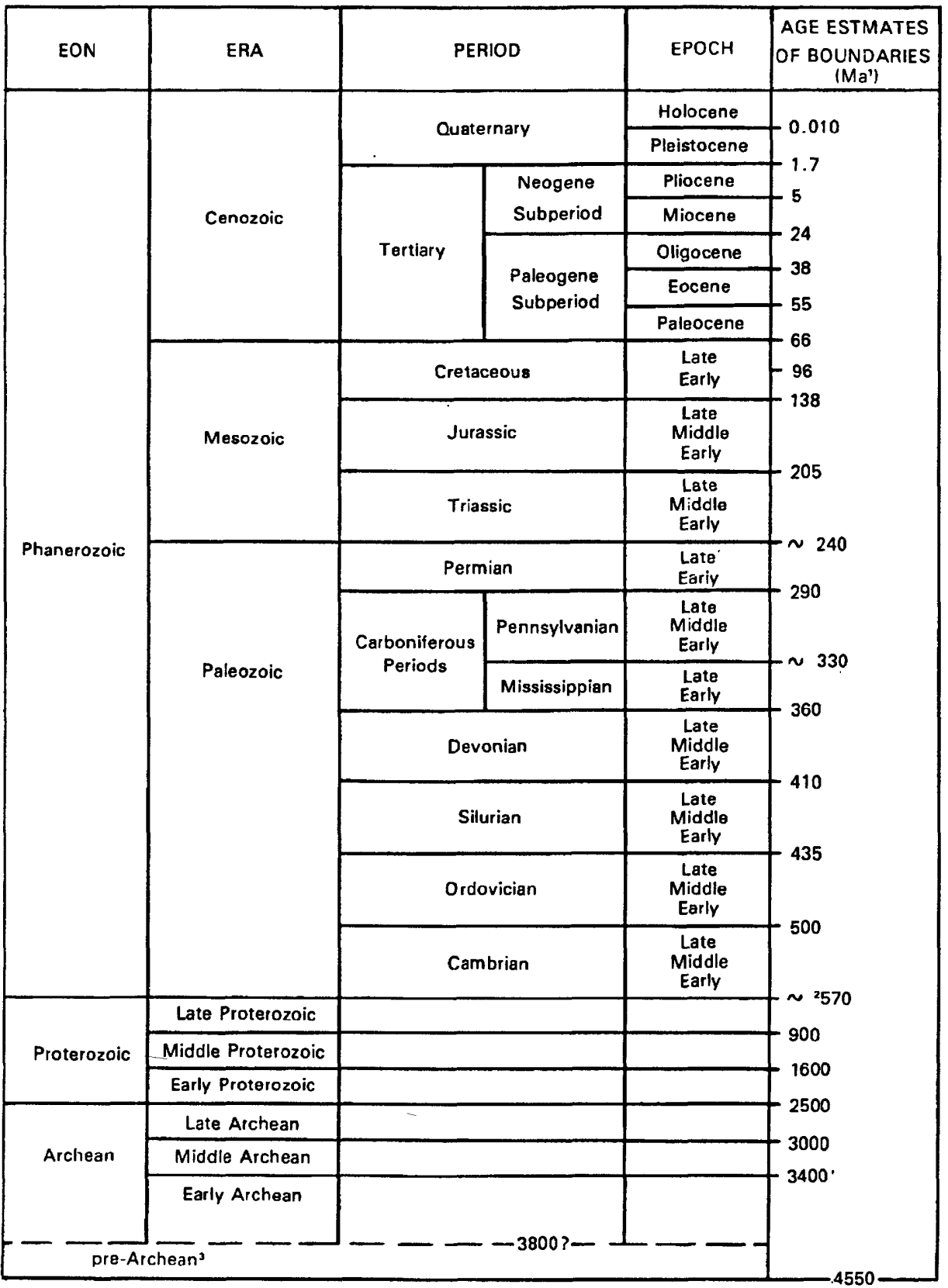

'Millions of years prior to A.D. 1950.

${ }^{2}$ Rocks older than $\mathbf{5 7 0}$ m.y. also called Precambrian, a time term without specific rank.

${ }^{3}$ Informal time term without specific rank. 